We thank Dr $M$ Jacobsen from the Institute of Occupational Medicine, Edinburgh, UK, Dr Mike Phillips, and Dr Xin Kai Lu, Centre for Advanced Studies, Australia for design and data processing. The cost was covered by a grant from the Ministry of Public Health of China.
1 SAS Institute. Logist procedure. In: Supplemental Library User's Guide, Version 5. Cary, NC: SAS Institute, 1986:662.

2 Jacobsen M, Rae S, Walton WH, Rogan JM. The relationship between pneumoconiosis and dust exposure in British coal mines. In: Walton WH, ed. Inhaled particles III. Old Woking, Surrey: Unwin Bros, 1971:903-19.

3 Hurley JF, Burs J, Copland L, Dodgson J, Jacobsen M. Coalworkers' simple pneumoconiosis and exposure to dust at 10 British coalmines. Br J Ind Med 1982;39:120-7.

Accepted 13 May 1991

\section{Inhalation Fever: A proposed unifying term for febrile reactions to inhalation of noxious substances}

Over the past several years there have been many publications that consider respiratory illnesses of farmers. ${ }^{1-3}$ Much of the interest has centred around the description of a febrile illness caused by exposure to organic dust that has been called several names including: grain fever, pulmonary mycotoxicosis, silo unloader's syndrome, and organic dust toxic syndrome (ODTS). There is now sufficient evidence to suggest that these febrile attacks are separate from allergic alveolitis. The physiological impact of the febrile illness on the lung is minimal whereas in allergic alveolitis one sees abnormal blood gases, chest radiographs, and pulmonary function tests. ${ }^{4}$

In the modern industrial era there has been extensive writing about febrile responses to the inhalation of metal fumes and dusts such as metal fume fever among welders and foundry workers. ${ }^{56} \mathrm{As}$ plastics emerged papers appeared describing febrile illnesses in those who work with complex polymers. ${ }^{7}$

The clinical picture of these inhalation ailments is similar. All have a latent period of several hours between the exposure and the onset of fevers, chills, malaise, myalgias, and chest tightness. Patients often have a leucocytosis with a left shift. ${ }^{289-11}$ There are reports of chemical pneumonitis and pulmonary oedema in some metal and plastic exposures and a single report suggesting more severe lung involvement after exposure to organic dust in an agricultural setting, but most reports suggest that little lung damage occurs. ${ }^{12-15}$

We are struck by the described similarities and believe that a generic term is best for this family of respiratory ailments. In the absence of a single aetiological agent for these very different exposures we think that the fevers and symptoms represent a common pathway in which the lung reacts to noxious substances. We suggest that they all be called inhalation fever, a term originating from $1978 .^{16}$ This avoids the colourful but confusing litany of names currently in use. Henceforth we propose that organic dust toxic syndrome, all the fume fevers, spelter shakes, mill fever, Monday fever, card room fever, and brass founders ague etc, be called simply Inhalation fever.

A RASK-ANDERSEN
Department of Occupational Medicine,
University Hospital,
S-75185 Uppsala, Sweden
D S PRATT
New York Center
for Agricultural Medicine and Health,
One Atwell Road, Cooperstown,
New York 13326, USA

1 Pratt DS, May JJ. Feed-associated respiratory illnesses in farmers. Arch Environ Health 1984;39:43-7.

2 Rask-Andersen A. Organic dust toxic syndrome among farmers. Br J Ind Med 1989;46:233-8.

3 Husman K, Terho E, Notkola V, Nuutinen J. Organic dust toxic syndrome among Finnish farmers. Am J Ind Med 1990;17: 79-80.

4 Malmberg P, Rask-Andersen A, Höglund S, KolmodinHedman B, Guernsey J. Incidence of organic dust toxic syndrome and allergic alveolitis in Swedish farmers. Int Arch Allergy Appl Immunol 1988;87:47-54.

5 Brodie J. Welding fumes and gases: Their effect on the health of the worker. California and Western Medicine 1943;59:13-8.

6 Drinker P, Thomson RM, Finn K. Metal fume fever: IV. Threshold doses of zinc oxide, preventive measures, and the chronic effects of repeated exposures. J Ind Hyg 1927;9: 331-45.

7 Harris DK. Polymer fume fever. Lancet 1951;7814:1008-11.

8 Pratt DS, Stallones L, Darrow D, May J. Acute respiratory illness associated with silo unloading. Am J Ind Med 1986, 10:328.

9 Mueller E, Seger D. Metal fume fever: A review. J Emerg Med $1985 ; 2: 271-4$.

10 Armstrong C, Moore L, Hackler R, Miller G, Stroube R. An outbreak of metal fume fever. J Occup Med 1983;25:886-8.

11 Nuttal J, Kelly RJ, Smith BS, Whiteside CK Jr. Inflight toxic reactions resulting from fluorocarbon resin pyrolysis. Aerospace Medicine 1964;35:676-83.

12 Dula D. Metal fume fever. Journal of the American College of Emergency Physicians 1978;7:448-50.

13 Anthony J, Zamel N, Aberman A. Abnormalities in pulmonary function after a brief exposure to toxic metal fumes. Can Med Ass $J$ 1978;119:586-8.

14 Robbins J, Ware R. Pulmonary edema from tefion fumes. New Engl J Med 1964;271:360-1.

15 Yoshida K, Ando M, Araki S. Acute pulmonary edema in a storehouse of moldy oranges: A severe case of the organic dust toxic syndrome. Arch Environ Health 1989;44:382-4.

16 Editorial. Inhalation fevers. Lancet 1978;4:249-50. 